\title{
Pengaruh Kepuasan Kerja Terhadap Organizational Citizenship Behavior (OCB) Dengan Komitmen Organisasional Sebagai Variabel Intervening (Studi pada PNS Rumah Sakit Umum Daerah Kabupaten Lombok Utara
}

\author{
Gatya Wija Phala ${ }^{1}$ \\ Siti Nurmayanti2 \\ Alamsyah ${ }^{2}$
}

\begin{abstract}
This study aims to the find out significant effect of: (1) Job Satisfaction on OCB. (2) Job Satisfaction on Organizational Commitment. (3) Organizational Commitment on OCB. (4) Job Satisfaction on OCB through Organizational Commitment as an intervening Variable. This is as case study conducted on Civil Servant of Regional Public Hospital of North Lombok Regency. The research design in a causal associative research. The population in this study were 66 Civil Servant. While data collection techniques are documentation, interview, and questionnaires to get answer as well as characteristics of respondents. This research then applies census method. In this research, to analyze the data, path analysis was used. The results shows that: (1) Job Satisfaction does not have significant effect on OCB. (2) Job Satisfaction has significant effect on the Organizational Commitment. (3) Organizational Commitment has significant effect on OCB. (4) Job Satisfaction has significant effect on OCB through Organizational Commitment of Civil Servant Working at Regional Public Hospital of North Lombok Regency.
\end{abstract}

Keywords: Organizational Citizenship Behavior, Organizational Commitment, and Job Satisfaction.

\section{PENDAHULUAN}

Organisasi merupakan sistem sosial dengan sumber daya manusia merupakan faktor utama untuk mencapai efektivitas dan efisiensi (Rad et al.,2006). Organisasi yang baik, dalam perkembangannya pastilah menitik beratkan pada sumber daya manusia (human resources) guna menjalankan fungsinya dengan optimal, khususnya demi menghadapi perubahan lingkungan yang terjadi (Paramita, 2008).

Organisasi dapat dikatakan efektif apabila para anggotanya dapat bekerja secara tim dan kinerja tim yang baik dapat dilihat dari interaksi yang baik antar anggotanya, baik pada tingkat individu, kelompok, dan sistem organisasi tersebut akan menghasilkan output manusia yang memiliki tingkat absensi yang rendah, perputaran pegawai(turn over) yang rendah, komitmen organisasi yang tinggi dan tercapainya kepuasan kerja dan para anggota yang memiliki Organizational Citizenship Behavior (Robbins \& Judge, 2008).

Organizational Citizenship Behavior (OCB) dianggap sebagai suatu perilaku ditempat kerja yang sesuai dengan penilaian pribadi yang melebihi persyaratan kerja dasar seseorang (Bateman \& Organ dalamTitisari, 2014). OCB sangat penting dalam kelangsungan hidup organisasi. OCB juga dapat memaksimalkan efisiensi dan

\footnotetext{
${ }^{1}$ Mahasiswa Pasca Sarjana UNRAM Program Magister Manajemen

2 Dosen Pasca Sarjana UNRAM Program Magister Manajemen
} 
produktivitas karyawan maupun organisasi yang pada akhirnya memberi kontribusi pada fungsi efektif dari suatu organisasi.

Podsakoff (2000, dalam Rohayati, 2012:21), menyatakan OCB dipengaruhi oleh dua faktor utama yaitu faktor yang berasal dari dalam diri karyawan (internal) seperti moral, rasa puas, sikap positif dan faktor yang berasal dari luar karyawan (eksternal) seperti sistem manajemen, sistem kepemimpinan dan budaya perusahaan.

Faktor internal yang dapat membentuk OCB salah satunya yang terpenting adalah kepuasan kerja, pernyataan tersebut sangat logis bahwa kepuasan kerja merupakan penentu utama OCB pegawai (Robbins, 2006). Menurut Wexley dan Yukl (1998) kepuasan kerja adalah perasaan seseorang karyawan mengenai pekerjaannya. Kepuasan kerja mencerminkan perasaan senang atau tidak senang seseorang karyawan terhadap yang dilakukannya dan dapat meningkatkan motivasi karyawan untuk hadir dan mengerahkan tenaga, pikiran dan waktu dalam melaksanakan pekerjaannya. Penelitian terkini mengungkapkan bahwa kepuasan kerja berpengaruh positif dan signifikan terhadap OCB. Penelitian yang dilakukan Rusdi, dkk (2015), menunjukkan bahwa kepuasan kerja dan loyalitas berpengaruh signifikan baik secara simultan dan parsial terhadap OCB. Penelitian berikutnya dilakukan oleh Rahmi (2013) yang menunjukkan kepuasan kerja berpengaruh positif dan signifikan terhadap OCB. Namun temuan yang berbeda ditunjukkan oleh hasil penelitian Darto, dkk. (2015) yang menemukan bahwa kepuasan kerja tidak berpengaruh signifikan terhadap OCB.

Faktor internal lainnya yang membentuk OCB yaitu komitmen organisasional. Komitmen organisasional memiliki arti suatu kondisi yang menggambarkan karyawan berpihak pada suatu organisasi dan tujuan-tujuannya dan berniat mempertahankan keanggotaannya dalam organisasi tersebut (Robbins \& Judge, 2013:108). Menurut Luthans (2001) komitmen organisasional adalah sikap yang mencerminkan kesetiaan pegawai terhadap organisasi mereka dan merupakan sebuah proses yang berkesinambungan dimana para pelaku organisasi mengekspresikan kepedulian mereka terhadap organisasi dan adanya keinginan agar organisasi terus sejahtera dan mendapatkan kesuksesan. Luthans juga menegaskan bahwa komitmen organisasional mempunyai hubungan yang positif dengan hasil-hasil yang diinginkan seperti kinerja yang tinggi, tingkat turnover yang rendah serta tingkat absensi yang rendah. Selain itu komitmen pegawai terhadap organisasi memiliki hubunan dengan hasil-hasil positif lainnya, seperti persepsi tentang suasana organisasi yang mendukung kerja dan kesediaan untuk saling tolong menolong sebagai anggota tim yang baik. Oleh karena itu, komitmen organisasional menimbulkan rasa saling memiliki di antara karyawan. Apabila lingkungan kerja menciptakan rasa puas maka dengan sendirinya karyawan akan cenderung lebih giat dan sungguh-sungguh dalam bekerja. Dengan sendirinya, hal itu mencerminkan sikap setia kepada organisasi.

Penelitian yang dilakukan oleh Vania dan Purba (2014) menemukan bahwa komitmen organisasional terbukti memiliki pengaruh full intervening pada pengaruh kepuasan kerja terhadap OCB dimana pengaruh kepuasan kerja menjadi tidak signifikan terhadap OCB). Berdasarkan model yang diajukan oleh Birnbaum dan Somers (1998) dan literatur teoritis dan penelitian empiris, dapat disimpulkan bahwa kepuasan kerja dan komitmen organisasional berhubungan positif dengan OCB. Banyak penelitian yang sudah dilakukan untuk menguji hubungan antara komitmen

\footnotetext{
${ }^{1}$ Mahasiswa Pasca Sarjana UNRAM Program Magister Manajemen

2 Dosen Pasca Sarjana UNRAM Program Magister Manajemen
} 
organisasional dengan OCB seperti yang dilakukan Pradhiptya (2013), menemukan bahwa kepuasan kerja berpengaruh signifikan terhadap OCB dengan di mediasi oleh Komitmen Organisasional. Sedangkan Ngadiman et al.,(2013) menemukan bahwa komitmen oraganisasional berpengaruh positif signifikan terhadap OCB. Penelitian yang dilakukan oleh Setiawan (2009) juga menunjukkan komitmen organisasional berpengaruh positif terhadap OCB. Vania \& Purba (2014) juga menemukan komitmen organisasional berpengaruh signifikan terhadap OCB secara parsial. Temuan yang berbeda ditunjukkan oleh penelitian oleh Sambung dan Iring (2014) yang menemukan bahwa komitmen organisasional tidak berpengaruh signifikan terhadap OCB.

Peningkatan pelayanan kesehatan merupakan salah satu prioritas pembangunan daerah di Kabupaten Lombok Utara dan sebagai fokus utama ditekankan pada upaya-upaya khusus untuk meningkatkan Umur Harapan Hidup (UHH) sebagai salah satu indikator dari Indeks Pembangunan Manusia (IPM). Rumah Sakit Umum Daerah Kabupaten Lombok Utara adalah Rumah Sakit Pemerintah Daerah, dan satu-satunya sarana pelayanan kesehatan rujukan yang ada di Kabupaten Lombok Utara. Rumah Sakit Umum Daerah Kabupaten Lombok Utara berdiri tahun 2010 melalui ijin Operasional Bupati No 964/898/DIKES/2010. Saat ini selain melaksanakan upaya penyembuhan dan pemulihan penyakit juga melaksanakan upaya peningkatan dan pencegahan penyakit.

Pegawai yang bekerja dengan menampilkan OCB cenderung bersedia untuk membantu orang lain secara sukarela, artinya dalam hal ini pegawai dapat memunculkan kinerja yang optimal ketika pegawai tidak hanya memenuhi harapan organisasi (in role)namun juga perilaku (ekstra role). Dalam situasi ini Organizational Citizenship Behavior (OCB) merupakan perilaku yang sangat cocok dikembangkan di Rumah Sakit Umum Daerah Kabupaten Lombok Utara.

Dalam proses pengembangannya Rumah Sakit Umum Daerah Kabupaten Lombok Utara mengupayakan peningkatan kinerja pegawainyanya dalam memberikan pelayanan yang maksimal bagi masyarakat. Tentu hal tersebut akan sangat didukung oleh faktor internal seperti kepuasan kerja dan komitmen organisasional pegawainya. Pegawai negeri sipil yang bekerja di RSUD Kabupaten Lombok Utara berperan penting untuk mencapai visi dan misi yang ingin dicapai dalam memberi pelayanan bidang kesehatan pada masyarakat. Hal ini tentu harus di kelola dengan baik agar peran serta dari PNS tersebut dalam mendukung kinerja rumah sakit akan meningkat dan bertambah baik. Sampai dengan tahun 2015, Rumah Sakit Umum Daerah Kabupaten Lombok Utara dalam melaksanakan tugas pokok dan fungsinya didukung oleh sumberdaya manusia (SDM) dari berbagai latar belakang pendidikan baik medis, paramedis maupun non medis.

Berbagai informasi yang diperoleh, peneliti menemukan permasalahan pada PNS di Rumah Sakit Umum Daerah Kabupaten Lombok Utara seperti pelaksanaan tugas yang tidak teratur sesuai dengan tugas pokok dan fungsi hal ini terlihat pada bidang pelayanan yaitu PNS yang mengurus standar pelayanan minimal belum menyelesaikan dokumen laporannya sementara pekerjaan lain yang bukan menjadi bidangnya menjadi fokus kerjanya seperti penerimaan staf baru di RSUD KLU yang seharusnya menjadi pekerjaan bidang kepegawaian. Dari berbagai permasalahan ini diindikasikan kurangnya komitmen pegawai terhadap pekerjaannya. Selain itu

\footnotetext{
${ }^{1}$ Mahasiswa Pasca Sarjana UNRAM Program Magister Manajemen

2 Dosen Pasca Sarjana UNRAM Program Magister Manajemen
} 
permasalahan lainnya yaitu tidak tepat waktu baik dalam bekerja maupun penyelesaian pekerjaan hal ini terlihat pada bidang panunjang medis dalam pengerjaan bangunan rumah sakit maupun pengadaan alat kesehatan yang masih belum tepat waktu sesuai dengan perencanaan, lebih mementingkan diri sendiri dalam bekerja persoalan ini terjadi pada bidang manajemen yang lebih mementingkan pekerjaannya sementara pekerjaan tersebut memerlukan koordinasi dengan bidang lain seperti pelayanan dan penunjang medis, kurangnya tanggungjawab PNS terhadap pekerjaanya terlihat hampir di semua bidang, masalah ini sering terjadi di RSUD KLU dimana para PNS belum adanya rasa tanggungjawab terhadap pekerjaannya, dimana pekerjaannya sebagian besar dilimpahkan pada staf atau tenaga kontrak yang menjadi bawahannya, sementara pekerjaan tersebut merupakan tugas pokok dan fungsinya sebagai penanggungjawab di bidang pekerjaan tersebut, dan masih tingginya absensi PNS terlihat hampir di semua bidang diamana masih ada beberapa PNS yang tidak hadir ke kantor untuk bekerja tanpa keterangan. Hal ini mengindikasikan ketidakpuasan terhadap pekerjaan dan organisasi.

Selain permasalahan mengenai PNS RSUD Kabupaten Lombok Utara diatas, peneliti juga menemukan OCB PNS yang positif seperti yang dijelaskan oleh McClelland et al. (1987) terdapat tiga tingkatan motif yang mendasari OCB yaitu : 1 . Motif berprestasi, mendorong orang untuk menunjukkan suatu standar keistimewaan (excellence), mencari prestasi dari tugas, kesempatan atau kompetisi. PNS di RSUD memiliki keinginan untuk berprestasi untuk memperoleh penghargaan dan kepercayaan dari pimpinan. 2. Motif afiliasi, mendorong orang untuk mewujudkan, memelihara dan memperbaiki hubungan dengan orang lain. Motif ini juga terdapat pada PNS di RSUD, terlihat pada saat jadwal piket khusus bagi pegawai yang piket, saat salah satu rekan kerjanya tidak dapat masuk maka rekan kerja yang lain menggantikannya. 3. Motif kekuasaan mendorong orang untuk mencari status dan situasi dimana mereka dapat mengontrol pekerjaan atau tindakan orang lain.Untuk motif ini sebagian besar PNS ingin memperoleh status lebih baik dari sebelumnya seperti kenaikan pangkat, golongan dan jabatan.

Berdasarkan fenomena permasalahan yang terjadi khususnya pada PNS di RSUD Kabupaten Lombok Utara dan research gap pada beberapa penelitian terdahulu, sehingga pada penelitian ini dilakukan untuk pengembangan beberapa penelitian terdahulu mengenai pengaruh kepuasan kerja terhadap Organizational Citizenship Behavior dengan komitmen organisasional sebagai variabel intervening. Selain itu hasil penelitian ini dapat digunakan oleh pengambil kebijakan di RSUD Kabupaten Lombok Utara sebagai referensi dalam pengambilan keputusan dalam rangka meningkatkan OCB PNS agar dapat lebih baik lagi dalam pekerjaanya.

\section{TUJUAN PENELITIAN}

a. Untuk menganalisis pengaruh kepuasan kerja terhadap Organizational Citizenship Behavior.

b. Untuk menganalisis pengaruh kepuasan kerja terhadap Komitmen Organisasional.

c. Untuk menganalisis pengaruh Komitmen Organisasional terhadap Organizational Citizenship Behavior.

\footnotetext{
${ }^{1}$ Mahasiswa Pasca Sarjana UNRAM Program Magister Manajemen

2 Dosen Pasca Sarjana UNRAM Program Magister Manajemen
} 
d. Untuk menganalisis pengaruh Kepuasan Kerja terhadap Organizational Citizenship Behavior melalui Komitmen Organisasional.

\section{LANDASAN TEORI}

\subsection{Organizational Citizenship Behavior (OCB)}

Organizational Citizenship Behavior merupakan kontribusi individu yang melebihi tuntutan peran ditempat kerja. OCB ini melibatkan beberapa perilaku meliputi perilaku menolong orang lain, menjadi volunteer untuk tugas-tugas ekstra, patuh terhadap aturan-aturan serta prosedur-prosedur di tempat kerja (Aldag \& Resckhe dalam Titisari, 2014).

OCB merupakan perilaku individual bebas untuk menentukan, yang tidak secara langsung atau eksplisit diakui oleh sistem reward formal dan secara bersamasama akan mendorong fungsi organisasi lebih efektif (Organ dalam Titisari, 2014). Terdapat bukti bahwa individu yang menunjukkan OCB memiliki kinerja lebih baik dan menerima evaluasi kinerja lebih tinggi dari organisasinya (Podsakoff \& Mackenzei dalam Titisari, 2014).

\subsection{Faktor-Faktor Yang Memengaruhi Organizational Citizenship Behavior (OCB)}

Menurut Organ et al., (2006:10) peningkatan OCB dipengaruhi oleh dua faktor utama yaitu faktor internal dan faktor eksternal.

\section{A. Faktor internal}

1. Kepuasan Kerja

Kepuasan kerja merupakan penentu utama Organizational Citizenship Behavior (OCB) karyawan (Robbins, 2006). Karyawan yang puas berkemungkinan lebih besar untuk berbicara secara positif tentang organisasi, membantu rekan kerja dan membuat kinerja pekerjaan mereka melampaui perkiraan normal, lebih dari itu karyawan yang puas mungkin lebih patuh terhadap panggilan tugas, karena mereka ingin mengulang pengalaman-pengalaman positif mereka.

2. Komitmen Organisasi

Faktor lain yang berperan dalam membentuk Organizational Citizenship Behavior (OCB) karyawan adalah komiten organisasi. banyak penelitian yang sudah dilakukan untuk menguji hubungan antara komitmen organisasi dengan Organizational Citizenship Behavior, seperti yang dilakukan oleh Chen dan Francesco (2000) meneliti hubungan antara tiga komponen dari komitmen dan kinerja karyawan di Cina, peneliti menemukan bahwa komitmen afektif berpengaruh positif pada pada kinerja in role dan Organizational Citizenship Behavior.

3. Kepribadian

Kepribadian juga bisa sebagai variabel pembentuk Organizational Citizenship Behavior. Organ dalam Titisari, 2014 berpendapat bahwa perbedaan individu merupakan prediktor yang memainkan peran penting pada seoarang karyawan sehingga karyawan tersebut akan menunjukkan Organizational Citizenship Behavior) mereka, maka diyakini bahwa beberapa orang yang memperlihatkan siapa mereka atau bagaimana mereka memperlihatkan kepribadian mereka akan lebih mungkin untuk mereka menampilkan OCB.

\footnotetext{
${ }^{1}$ Mahasiswa Pasca Sarjana UNRAM Program Magister Manajemen

2 Dosen Pasca Sarjana UNRAM Program Magister Manajemen
} 
4. Moral Karyawan

Menurut Djati dalam Titisari (2014:25) moral berasal dari bahasa latin yaitu mores yang berarti kesusilaan, tabiat atau kelakuan. Moral memuat ajaran atau ketentuan baik dan buruk suatu tindakan yang dilakukan dengan sengaja.Dapat diartikan bahwa moral merupakan kewajiban-kewajiban susila seseorang terhadap masyarakat atau dalam konteks penelitian ini terhadap organisasi.sasaran moral adalah keserasian atau keselarasan perbuatan-perbuatan manusia dengan aturan-aturan mengenai perbuatan-perbuatan manusia itu sendiri (Salam,2000).

5. Motivasi

Motivasi dapat diartikan sebagai kekuatan (energi) seseorang yang dapat menimbulkan tingkat persistensi dan antusiasmenya dalam melaksanakan suatu kegiatan, baik yang bersumber dari dalam individu itu sendiri (motivasi intrinsik) maupun dari luar individu (motivasi ekstrinsik). Seberapa kuat motivasi yang dimiliki individu akan banyak menentukan terhadap kualitas perilaku yang ditampilkannya, baik dalam konteks belajar, bekerja maupun dalam kehidupan lainnya.

\section{B. Faktor Eksternal}

1. Kepemimpinan Situasional

Variabel lain yang dapat membentuk Organizational Citizenship Behavior (OCB) adalah gaya kepemimpinan. Shahzad et al (dalam Titisari, 2014: 44) menemukan bahwa gaya kepemimpinan berpengaruh signifikan terhadap Organizational Citizenship Behavior (OCB). Berdasarkan hasil penelitian Alhamda (dalam Titisari, 2014:44) terlihat bahwa perilaku kepemimpinan dan Organizational Citizenship Behavior (OCB) pada Poltekkes Padang belum baik, tetapi kinerja dosen sudah baik.

2. Kepercayaan Pada Pimpinan

Faktor lain yang menjadi perhatian juga adalah kepercayaan pada pimpinan (trust in leader). Podsakoff et al. (dalam Titisari, 2014:53) menyatakan bahwa kepercayaan terhadap pimpinan dapat memperkuat hubungan kepemimpinan transformasional terhadap Organizational Citizenship Behavior.Kepercayaan terhadap pimpinan didefinisikan sebagai kunci mediasi hubungan antara kepemimpinan transformasional dengan Organizational Citizenship Behavior (OCB) yang didukung oleh penelitian Mackenzie et al (2001).

3. Budaya Organisasi

Terminologi tentang budaya organisasi tampaknya tidak dapat didefinisikan secara singkat. Menurut pandangan antropologis budaya didefinisikan sebagai program mental kolektif dari orang-orang dalam suatu masyarakat yang mengembangkan nilai-nilai kepercayaan dan perilaku yang sama. Kajian budaya organisasi menurut Schein (dalam Titisari, 2014: 55) yaitu budaya organisasi mengacu pada sistem makna bersama yang dianut oleh anggota yang membedakan organisasi itu terhadap organisasi yang lain.

4. Kepemimpinan Transformasional

Tanggungjawab utama dari seorang pimpinan organisasi adalah mengarahkan bawahannya ke arah pencapaian tujuan organisasi dengan jalan mengartikulasikan misi, visi, strategi dan sasaran-sasaran Zaccaro dan Klimosko (dalam Titisari, 2015:59).Pimpinan pada setiap tingkatan bertanggungjawab atas diseminasi tujuan-

\footnotetext{
${ }^{1}$ Mahasiswa Pasca Sarjana UNRAM Program Magister Manajemen

2 Dosen Pasca Sarjana UNRAM Program Magister Manajemen
} 
tujuan strategis organisasi dan meyakinkan para pengikutnya untuk mengimplementasikan tujuan-tujuan tersebut secara efektif, (Bersona \& Avolio dalam Titisari, 2015:59).

\subsection{Dimensi Organizational Citizenship Behavior (OCB)}

Supratman, (2013). Variabel OCB diukur dengan menggunakan indikator sebagai berikut :

a. Altruism, dengan unsur pengukur seperti :

1. Menggantikan rekan kerja yang tidak masuk atau istirahat;

2. Membantu orang lain yang pekerjaanya overload;

3. Membantu proses pekerjaan karyawan meskipun tidak diminta;

4. Membantu mengerjakan tugas orang lain pada saat dia tidak masuk;

5. Meluangkan waktu untuk membantu orang lain berkaitan dengan permasalahan-permasalahan pekerjaan;

6. Menjadi volunteer untuk mengerjakan sesuatu tanpa diminta;

7. Membantu orang lain diluar departemen ketika mereka menghadapi permasalahan;

8. Membantu pelanggan atau para tamu jika mereka membutuhkan bantuan.

b. Sportsmanship, dengan unsur-unsur seperti :

1. Tidak menemukan kesalahan dalam organisasi;

2. Tidak mengeluh tentang segala sesuatu;

3. Tidak membesar-besarkan kesalahan diluar proporsinya.

c. Conscientiousness, dengan unsur-unsur pengukur seperti :

1. Tiba lebih awal sehingga siap bekerja pada saat jadwal kerja dimulai;

2. Tepat waktu setiap hari tidak peduli pada musim ataupun lalu lintas dan sebagainya;

3. Berbicara seperlunya dalam percakapan di telepon;

4. Tidak menghabiskan waktu untuk pembicaraan diluar pekerjaan;

5. Datang segera jika dibutuhkan;

6. Tidak mengambil kelebihan waktu meskipun memiliki ekstra 6 hari.

d. Civic Virtue, dengan unsur-unsur pengukuran seperti :

1. Mengikuti perubahan-perubahan dan perkembangan-perkembangan dalam organisasi;

2. Membaca dan mengikuti pengumuman-pengumuman organisasi;

3. Membuat pertimbangan dan menilai apa yang terbaik untuk organisasi.

e. Courtesy,dengan unsur-unsur pengukuran seperti :

1. Memberikan perhatian-perhatian terhadap fungsi-fungsi yang membantu image organisasi;

2. Memberikan perhatian terhadap pertemuan-pertemuan yang dianggap penting;

3. Membantu mengatur kebersamaan secara departemental.

\subsection{Kepuasan Kerja}

Menurut Robbin (2001 : 91) kepuasan kerja adalah sikap umum seseorang individu terhadap pekerjaannya. Seseorang dengan tingkat kepuasan kerja yang tinggi

\footnotetext{
${ }^{1}$ Mahasiswa Pasca Sarjana UNRAM Program Magister Manajemen

2 Dosen Pasca Sarjana UNRAM Program Magister Manajemen
} 
menunjukkan sikap positif terhadap kerja itu sedangkan seseorang yang tidak puas dengan pekerjaannya menunjukkan sikap yang negatif terhadap pekerjaan itu.

Kepuasan kerja merupakan sikap fundamental yang terkait dengan pekerjaan yang didalamnya terdapat tiga komponen sikap, yaitu komponen evaluasi yang merujuk pada perasaan menyukai atau tidak meyukai terhadap seseorang, sesuatu atau peristiwa atau apapun yang menjadi obyek sikap; kognisi merupakan hal-hal yang diyakini berkaitan dengan obyek sikap dan tingkah laku, merupakan kecenderungan untuk berperilaku dalam cara yang konsisten dengan keyakinan dan kepercayaan mengenai obyek sikap (Green Berg \& Baron, 2003 dalam Nurmayanti, 2014).

\subsection{Dampak Kepuasan Kerja dan Ketidakpuasan}

Ada konsekuensi ketika pegawai menyukai pekerjaan mereka, danada konsekuensi ketikapegawai tidak menyukai pekerjaan mereka. Respons-respons tersebut didefinisikan sebagai berikut (Robbins dan Judge, 2008:111)

1) Pengabaikan (neglect) : secara pasif membiarkan kondisi menjadi lebih buruk, termasuk ketidakhadiran atau keterlambatan yang terus menerus, kurangnya usaha dan meningkatnya angka kesalahan.

2) Keluar (exit) : Perilaku yang ditujukan untuk meninggalkan organisasi, termasuk mencari posisi baru dan mengundurkan diri.

3) Aspirasi (voice) : secara aktif dan konstruktif berusaha memperbaiki kondisi, termasuk menyarankan perbaikan, mendiskusikan masalah dengan atasan, dan beberapa bentu aktivitas serikat kerja.

4) Kesetiaan (loyality) : secara pasif tetapi optimis menunggu membaiknya kondisi, termasuk membela organisasi ketika berhadapan dengan kecaman eksternal dan mempercayai organisasi dan manajemennya untuk melakukan hal yang benar.

\subsection{Komitmen Organisasional}

Komitmen organisasional menurut sopiah (2008) identifikasi dan keterlibatan seseorang yang relatif kuat terhadap organisasi. Karyawan yang memiliki komitmen kuat terhadap organisasinya merupakan suatu modal dalam mencapai tujuan organisasi sehingga memberikan manfaat maksimal bagi organisasi. Komitmen karyawan yang diberikan pada organisasi juga diperlukan untuk menyelesaikan masalah-masalah internal organisasi seperti berkurangnya biaya kegiatan operasional dan konflik dalam organisasi.

Ensher et al. (2001) mendefinisikan komitmen organisasional sebagai kekuatan relatif dari identifikasi dan keterlibatan seorang individu dalam organisasi tertentu dengan keyakinan yang dalam dan penerimaan atas tujuan dan nilai suatu organisasi, kesediaan untuk mengerahkan upaya cukup besar demi kepentingan organisasi, dan suatau keinginan kuat untuk mempertahankan keanggotaan dalam organisasi. atau dengan kata lain komitmen organisasional adalah ikatan psikologis yang dimiliki seorang pekerja pada suatu organisasi dan terkait pada suatu keselarasan tujuan dan nilai, investasi-investasi perilaku dalam organisasi, dan kemungkinan untuk tinggal dalam organisasi.

Pendekatan psikologis dikonsepkan pertama kali oleh Smith (dalam Titisari, 2014).Menurut Smith komitmen adalah orientasi aktif dan positif terhadap

\footnotetext{
${ }^{1}$ Mahasiswa Pasca Sarjana UNRAM Program Magister Manajemen

2 Dosen Pasca Sarjana UNRAM Program Magister Manajemen
} 
organisasi.berdasarkan pendapat ini komitmen memiliki 3 komponen orientasi yaitu identifikasi tujuan dan nilai-nilai organisasional, keterlibatan yang tinggi dalam lingkungan kerja dan kesetiaan pada organisasi.

\subsection{Indikator Komitmen Organisasional}

Meyer \& Allend (dalam Titisari, 2014), membagi komitmen menjadi tiga kelompok yaitu :

1. Komitmen afektif

Komitmen afektif mengacu pada emosi yang melekat pada karyawan untuk mengidentifikasi dan melibatkan dirinya dengan organisasi.karyawan dengan komitmen afektif yang kuat cenderung secara terus menerus akan setia pada organisasi karena memang begitu keinginan mereka yang sebenarnya ada dalam hati mereka.

2. Komitmen normatif

Komitmen normatif mengacu pada refleksi perasaan akan kewajiban untuk menjadi karyawan perusahaan. Karyawan dengan komitmen normatif yang tinggi merasa bahwa mereka memang seharusnya tetap bekerja pada organisasi tempat mereka bekerja sekarang.

3. Komitmen berkelanjutan

Komitmen yang berkelanjutan mengacu pada kesadaran karyawan yang berkaitan dengan akibat meninggalkan organisasi.

\section{KERANGKA KONSEPTUAL}

\section{(a). Gambar Kerangka Konseptual}

Adapun kerangka konseptual dalam penelitian ini, terlihat garis putus-putus memiliki makna bahwa OCB dapat dipengaruhi oleh kepuasan kerja melalui komitmen organisasional. Sedangkan garis panah lurus adalah pengaruh langsung antara kepuasan kerja tehadap OCB, kepuasan kerja terhadap komitmen organisasional, komitmen organisasional terhadap OCB.

\section{Gambar 1. Kerangka Konseptual}

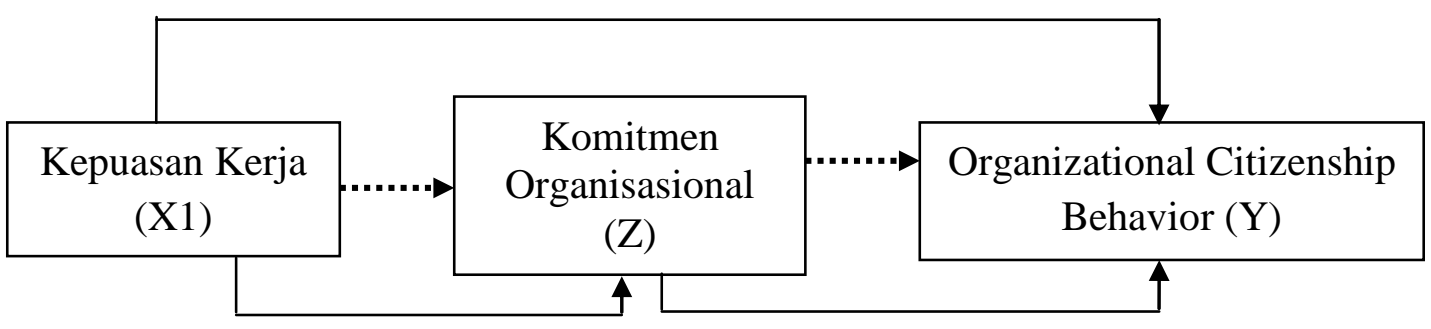

(b). Hipotesis

1) Diduga kepuasan kerja berpengaruh positif dan signifikan terhadap Organizational Citizenship Behavior.

2) Diduga kepuasan kerja berpengaruh positif dan signifikan terhadap komitmen organisasional.

3) Diduga komitmen organisasional berpengaruh positif dan signifikan terhadap Organizational Citizenship Behavior.

\footnotetext{
${ }^{1}$ Mahasiswa Pasca Sarjana UNRAM Program Magister Manajemen

2 Dosen Pasca Sarjana UNRAM Program Magister Manajemen
} 
4) Diduga kepuasan kerja berpengaruh positif dan signifikan terhadap Organizational Citizenship Behavior melalui komitmen organisasional.

\section{METODE PENELITIAN}

\subsection{Populasi dan Responden Penelitian}

Menurut (Sugiyono, 2013:80), populasi adalah wilayah generalisasi yang terdiri atas: obyek/subyek yang mempunyai kualitas dan karakteristik tertentu yang ditetapkan oleh peneliti untuk dipelajari dan kemudian ditarik kesimpulannya. Metode pengumpulan data yang digunakan dalam penelitian ini adalah metode sensus. Yang menjadi responden dalam penelitian ini adalah seluruh Pegawai Negeri Sipil di RSUD Kabupaten Lombok Utara dengan jumlah populasi sejumlah 66 orang responden.

\subsection{Analisis Path}

Dalam penelitian ini teknik analisis data yang digunakan adalah path analysis (analisis jalur). Analisis ini bertujuan untuk mencari pengaruh langsung dan tidak langsung seluruh variabel eksogenus tehadap variabel endogenus, serta mencari pengaruh langsung dan tidak langsung antara variabel endogenus dengan variabel endogenus lainnya. Adapun langkah-langkah menurut Solimun, 2002 (dalam Fitrijayanti, 2014:55) adalah sebagai berikut :

1) Dalam analisis path model dirancang berdasarkan kerangka konseptual penelitian, dengan rumus sebagai berikut :
a. Kepuasan kerja berpengaruh positif dan signifikan terhadap OCB.
b. Kepuasan kerja berpengarug positif dan signifikan terhadap komitmen organisasional.
c. Komitmen organisasional berpengaruh positif dan signifikan terhadap OCB.
d. Kepuasan kerja berpengaruh positif dan signifikan terhadap OCB melalui komitmen organisasional.
Berdasarkan hubungan antar variabel di atas, model ekonometrik menjadi sebagai berikut:
a. $Z=\gamma x$
b. $Y=\gamma x$
c. $\mathrm{Y}=\beta \mathrm{Z}$
Atau :
a. Komitmen Organisasional $=\gamma$ kepuasan kerja
b. $\mathrm{OCB}=\gamma$ kepuasan kerja
c. $\mathrm{OCB}=\beta$ komitmen organisasional

Formulasi tersebut dapat dijelaskan sebagai berikut :

a) Komitmen organisasional (Z) sebagai variabel intervening; organizational citizenship behavior $(Y)$ sebagai variabel endogen; dan kepuasan kerja $(X)$ sebagai variabel eksogen.

b) Parameter $\gamma$ (gamma) adalah parameter pengaruh variabel eksogen terhadap variabel endogen.

c) Parameter $\beta$ (beta) yaitu parameter pengaruh variabel intervening terhadap variabel endogen.

\footnotetext{
${ }^{1}$ Mahasiswa Pasca Sarjana UNRAM Program Magister Manajemen

2 Dosen Pasca Sarjana UNRAM Program Magister Manajemen
} 
d) Parameter $\varepsilon$ (eoileson) yaitu parameter yang berkenaan dengan error pada pengukuran variabel laten berdasarkan variabel manifes.

2) Pemeriksaan terhadap asumsi yang melandasi

Asumsi yang melandasi analysis path adalah :

a. Di alam model path analysis, hubungan antar variabel adalah leanier dan aditing.

b. Hanya model rekursif dapat dipertimbangkan, yaitu hanya sistem aliran causal ke satu arah, rekursif apabila memenuhi asumsi berikut :

- Antara $\varepsilon_{1}$ saling bebas (independent)

- Antara $\varepsilon_{1} \ldots \ldots . . . \varepsilon_{n}$ dengan $x_{1}, x_{2}, x_{3}$ saling bebas

- Variabel endogen minimal dalam skala ukur interval

- Observasi variabel diukur tanpa kesalahan (instrument pengukuran valid dan reliabel)

- Model yang dianalisis diidentifikasi dengan benar berdasarkan teori dan konsep-konsep yang relevan.

3) Penduga parameter atau perhitungan koofisien path

Perhitungan koofisien pada gambar model penelitian dapat dijelaskan sebagai berikut : anak panah satu arah $(\longrightarrow$ ) digunakan perhitungan regresi yang telah dilakukan pada masing-masing persamaan. Metode yang digunakan adalah OLS (Ordiary Least Square) yaitu metode kuadrat terkecil biasa.

4) Pemeriksaan validitas model

Sahih atau tidaknya suatu hasil analisis bergantung terpenuhi atau tidaknya dua indikator validitas model analisis jalur (path analysis), yaitu koefisien determinasi total dan teori trimming.

a. Koefisien determinasi total

Total keragaman data yang dapat dijelaskan oleh model diukur dengan $: R m^{2}=$

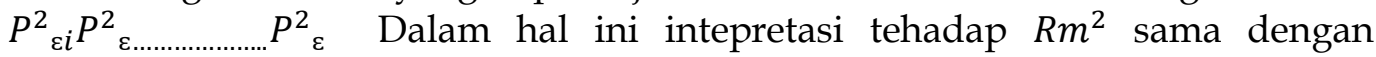
intepretasi koefisien determinasi $\left(R^{2}\right)$ pada analisis regresi.

b. Teori trimming

Uji validitas koefisien path pada setiap jalur untuk pengaruh langsung adalah sama dengan regresi, menggunakan nilai $p$ dari uji $t$, yaitu pengujian koefisien regresi variabel dibakukan secara parsial. Berdasarkan theory triming, maka jalur-jalur yang non signifikan dibuang, sehingga diperoleh model yang mendukung oleh data empirik.

5) Langkah terakhir di dala path analysis adalah melakukan intepretasi hasil analisis. Pertama, dengan memperhatikan hasil validitas model. Kedua, hitung pengaruh total dari setiap variabel yang mempunyai pengaruh kausal ke variabel endogen. Tingkat signifikan ditentukan sebesar 0,05 (5\%).

\footnotetext{
${ }^{1}$ Mahasiswa Pasca Sarjana UNRAM Program Magister Manajemen

2 Dosen Pasca Sarjana UNRAM Program Magister Manajemen
} 


\section{HASIL PENELITIAN}

6.1. Karakristik Responden Berdasarkan Usia

Jumlah responden dengan rincian menurut kelompok usia dapat dilihat pada tabel 2. dibawah ini :

Tabel 2. Karakteristik Responden PNS RSUD KLU

\begin{tabular}{|c|c|c|c|}
\hline \multicolumn{2}{|c|}{ Karakteristik Responden } & Frekuensi (org) & Persentase (\%) \\
\hline \multirow{3}{*}{ Usia (Tahun) } & $26-35$ & 19 & $28 \%$ \\
\cline { 2 - 4 } & $36-45$ & 29 & $43 \%$ \\
\cline { 2 - 4 } & $>46$ & 18 & $27 \%$ \\
\hline Jenis Kelamin & Laki-laki & 25 orang & $37 \%$ \\
\cline { 2 - 4 } & Perempuan & 41 orang & $62 \%$ \\
\hline \multirow{3}{*}{$\begin{array}{c}\text { Tingkat } \\
\text { Pendidikan }\end{array}$} & SMA/SMK & 5 & $7 \%$ \\
\cline { 2 - 4 } & D III & 33 & $50 \%$ \\
\cline { 2 - 4 } & S 1 & 26 & $39 \%$ \\
\hline Masa Kerja & S 2 & 2 & $3 \%$ \\
\cline { 2 - 4 } & $<5$ & 66 & $100 \%$ \\
\hline \multicolumn{2}{|c|}{ Total } & 0 & $\mathbf{6 6}$ orang \\
\hline
\end{tabular}

Sumber: Data primer diolah, 2016

Berdasarkan tabel 3. diatas dapat dilihat bahwa responden lebih dominan berusia 36 - 45 tahun sebanyak 29 orang (43\%). Pada usia 36-45 tahun ini adalah merupakan umur produktif bagi pegawai RSUD KLU, sehingga mereka mampu untuk melakukan pekerjaan yang ada pada Rumah Sakit.

Berdasarkan jenis kelamin, jumlah responden perempuan labih banyak dari jumlah responden laki-laki pada RSUD KLU menunjukan bahwa dibagian pelayanan perempuan lebih mendominasi pekerjaan pada rumah sakit.

Berdasarkan tingkat pendidikan dapat dilihat bahwa responden dengan tingkat pendidikan D3 merupakan tingkat pendidikan yang mendominasi tingkat pendidikan pegawai pada RSUD KLU karena dengan tingkat pendidikan D3 sudah sesuai dengan karakteristik tingkat pekerjaan yang ada pada RSUD tersebut.

Sedangkan responden dengan masa kerja kurang dari 5 tahun atau 100\%. Hal ini dikarenakan RSUD Kabupaten Lombok Utara baru terbentuk pada tahun 2012 yang pada awalnya merupakan Puskesmas Tanjung. Sehingga sampai dengan saat ini seluruh pegawai negeri sipil di RSUD Kabupaten Lombok Utara masa kerjanya $<5$ tahun semenjak berdirinya RSUD.

\subsection{Analisis Path}

6.2.1. Analisis Pengaruh Langsung Antar Variabel

1. Kepuasan Kerja $\left(X_{1}\right)$ Terhadap Komitmen Organisasional $(Z)$

Untuk mengetahui apakah variabel kepuasan kerja $\left(X_{1}\right)$ mempunyai pengaruh langsung terhadap Komitmen Organisasional (Z), dapat dilihat pada output path analysis yang dihasilkan oleh Amos Versi 22, yang dirangkum pada tabel 3. berikut:

\footnotetext{
1 Mahasiswa Pasca Sarjana UNRAM Program Magister Manajemen

2 Dosen Pasca Sarjana UNRAM Program Magister Manajemen
} 
$J M M$

UNRAM
JURNAL MAGISTER MANAJEMEN

UNIVERSITAS MATARAM

September 2016

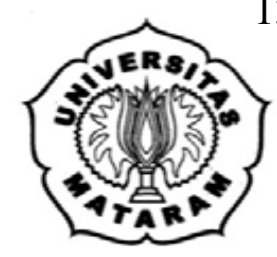

Tabel 3. Pengaruh Langsung Kepuasan Kerja Terhadap

Komitmen Organisasional (Z)

\begin{tabular}{|c|c|c|c|c|}
\hline Variabel & Koefisien Jalur & CR & Signifikansi & Keterangan \\
\hline $\begin{array}{l}\left.\text { Kepuasan Kerja ( } \mathbf{X}_{\mathbf{1}}\right) \text { Komitmen } \\
\text { Organisasional (Z) }\end{array}$ & 0,318 & 4,709 & 0,000 & Signifikan \\
\hline
\end{tabular}

Sumber : Data primer diolah, 2016 (lampiran 6)

Dari Tabel 3. di atas, variabel kepuasan kerja $\left(X_{1}\right)$ nilai signifikansinya sebesar 0,000 artinya variabel kepuasan kerja memiliki pengaruh langsung terhadap komitmen organisasional (Z) nilai signifikansinya lebih kecil dari taraf signifikansi yang disyaratkan $(<0,05)$.

Analisis path dapat pula disajikan dalam bentuk persamaan berikut:

Komitmen Organisasional $(\mathrm{Z})=0,318 \mathrm{X}_{1}$

Atau

Komitmen Organisasional $(Z)=2,153+0,318 X_{1}$

$\mathrm{R}^{2}=0,254$

Berdasarkan model-model pengaruh tersebut, maka dapat disusun model lintasan pengaruh langsung seperti terlihat pada Gambar 3. Model lintasan ini disebut dengan analisis path, dimana pengaruh error ditentukan sebagai berikut:

$$
\begin{aligned}
\varepsilon_{\mathrm{i}} & =\sqrt{ }\left(1-\mathrm{R}_{\mathrm{i}}^{2}\right) \\
\varepsilon_{1} & =\sqrt{ }(1-0,254)=\sqrt{ } 0,746
\end{aligned}
$$

Gambar 2. Model Lintasan Pengaruh Langsung Variabel Kepuasan Kerja $\left(\mathrm{X}_{1}\right)$ Terhadap Komitmen Organisasional (Z)

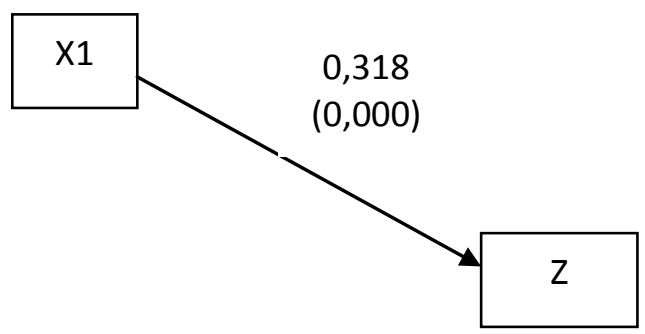

Dari Gambar 2. di atas, dapat dilihat bahwa terdapat pengaruh yang signifikan antara variabel kepuasan $\operatorname{kerja}\left(\mathrm{X}_{1}\right)$ sebesar 0,000 terhadap variabel komitmen organisasional (Z).

\footnotetext{
1 Mahasiswa Pasca Sarjana UNRAM Program Magister Manajemen

2 Dosen Pasca Sarjana UNRAM Program Magister Manajemen
} 


\section{Analisis Pengaruh Langsung Kepuasan Kerja $\left(X_{1}\right)$ dan Komitmen} Organisasional (Z) Terhadap Organizational Citizenship Behavior (Y)

Untuk mengetahui apakah variabel-variabel kepuasan kerja $\left(X_{1}\right)$ dan komitmen organisasional $(Z)$ mempunyai pengaruh langsung terhadap Organizational Citizenship Behavior (Y)dapat dilihat pada output path analysis yang dihasilkan oleh Amos Versi 22, yang dirangkum pada Tabel 4 . berikut.

Tabel 4. Pengaruh Langsung Kepuasan Kerjadan Komitmen Organisasional Terhadap Organizational Citizenship Behavior

\begin{tabular}{|l|c|c|c|c|}
\hline \multicolumn{1}{|c|}{ Variabel } & $\begin{array}{c}\text { Koefisien } \\
\text { Jalur }\end{array}$ & CR & Signifikansi & Keterangan \\
\hline Kepuasan Kerja $\left(\mathrm{X}_{1}\right) \longrightarrow$ OCB (Y) & 0,059 & 0,770 & 0,441 & $\begin{array}{c}\text { Tidak } \\
\text { Signifikan } \\
\text { Komitmen Organisasional }(\mathrm{Z}) \rightarrow \text { OCB }(\mathrm{Y})\end{array}$ \\
0,524 & 4,285 & 0,000 & Signifikan \\
\hline
\end{tabular}

Sumber : Data primer diolah, 2016 (lampiran 6)

Dari Tabel 4. di atas, variabel kepuasan kerja $\left(X_{1}\right)$ berpengaruh tetapi tidak signifikan terhadap organizational citizenship behavior $(\mathrm{Y})$ dengan nilai signifikansi sebesar 0,441, dan koefisien jalur 0,059. Sedangkan komitmen organisasional (Z) berpengaruh langsung terhadap organizational citizenship behavior (Y), dengan nilai signifikansi sebesar 0,000. Dan koefisien jalur 0,524.

Analisis path dapat disajikan dalam bentuk persamaan berikut.

Kepuasan kerja $\rightarrow$ OCB $(\mathrm{Y})=0,059$ X1

Komitmen Organisasional $\rightarrow$ OCB $(\mathrm{Y})=0,524 \mathrm{Z}$

Atau

Kepuasan kerja $\rightarrow$ OCB $(\mathrm{Y})=1,693+0,059 X 1$

Komitmen Organisasional $\rightarrow$ OCB $(Y)=1,693+0,524 \mathrm{Z}$

$\mathrm{R}^{2}=0,315$

Berdasarkan model-model pengaruh tersebut, maka dapat disusun model lintasan pengaruh analisis path seperti terlihat pada Gambar 3, dimana pengaruh error ditentukan sebagai berikut:

$$
\begin{aligned}
& \varepsilon_{\mathrm{i}}=\sqrt{ }\left(1-\mathrm{R}_{\mathrm{i}^{2}}\right) \\
& \varepsilon_{2}=\sqrt{ }(1-0,315)=\sqrt{ } 0,685
\end{aligned}
$$

\footnotetext{
${ }^{1}$ Mahasiswa Pasca Sarjana UNRAM Program Magister Manajemen

2 Dosen Pasca Sarjana UNRAM Program Magister Manajemen
} 


\section{Gambar 3. Model Lintasan Pengaruh Langsung Kepuasan Kerja dan Komitmen Organisasional Terhadap OCB}

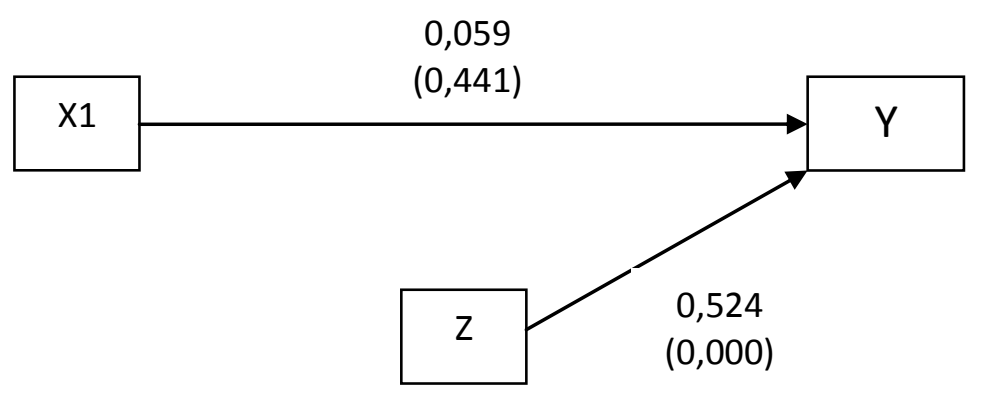

Dari Gambar 3. di atas, dapat dilihat bahwa varibel Kepuasan Kerja tidak berpengaruh signifikan terhadap $\mathrm{OCB}$, dimana kepuasan kerja $\left(\mathrm{X}_{1}\right)$ menunjukkan nilai signifikan sebesar 0,441 terhadap OCB (Y) sedangkan variabel komimen organisasional (Z) terdapat pengaruh positif dan signifikan sebesar 0,000 terhadap OCB (Y).

\subsubsection{Analisis Pengaruh Tidak Langsung Kepuasan Kerja Terhadap OCB Melalui Komitmen Organisasional}

Besarnya pengaruh tidak langsung kepuasan kerja $\left(\mathrm{X}_{1}\right)$ terhadap OCB $(\mathrm{Y})$ melalui komitmen organisasional (Z), diperoleh dari perkalian antar koefisien jalur tiap-tiap kepuasan kerja $\left(\mathrm{X}_{1}\right)$ dengan nilai koefisien dari komitmen organisasional $(\mathrm{Z})$. Besarnya pengaruh tidak langsung dari variabel-variabel tersebut, nilainya dapat dilihat pada Tabel 4.14.berikut:

Tabel 5. Pengaruh Tidak Langsung Kepuasan Kerja Terhadap OCB Melalui Komitmen Organisasional

\begin{tabular}{|c|c|c|}
\hline Variabel & Perkalian Koefisien Jalur & Hasil \\
\hline $\mathrm{X} 1 \rightarrow \mathrm{Z} \rightarrow \mathrm{Y}$ & $0,318 \times 0,524$ & 0,167 \\
\hline
\end{tabular}

Sumber : Data primer diolah, 2016 (lampiran 6)

Berdasarkan Tabel 5. di atas dapat dilihat, variabel kepuasan kerja $\left(X_{1}\right)$ memberikan pengaruh tidak langsung pada variabel OCB (Y) melalui variabel komitmen organisasional (Z) sebesar 0,167.

\subsubsection{Uji Validitas Model Penelitian}

Berdasarkan model-model pengaruh yang sudah dijelaskan di atas, maka dapat dibuat model lintasan pengaruh analisis path secara keseluruhan, yang merupakan gabungan antara lintasan pengaruh langsung variabel kepuasan kerja $\left(X_{1}\right)$ terhadap Komitmen organisasional $(Z)$, ditambah variabel kepuasan kerja $\left(X_{1}\right)$ dan komitmen organisasional $(\mathrm{Z})$ terhadap OCB $(\mathrm{Y})$, seperti terlihat pada Gambar 4. berikut:

\footnotetext{
${ }^{1}$ Mahasiswa Pasca Sarjana UNRAM Program Magister Manajemen

2 Dosen Pasca Sarjana UNRAM Program Magister Manajemen
} 


\section{Gambar 4. Model Gabungan Lintasan Pengaruh Variabel Kepuasan Kerja dan Komitmen Organisasional terhadap OCB (Y)}

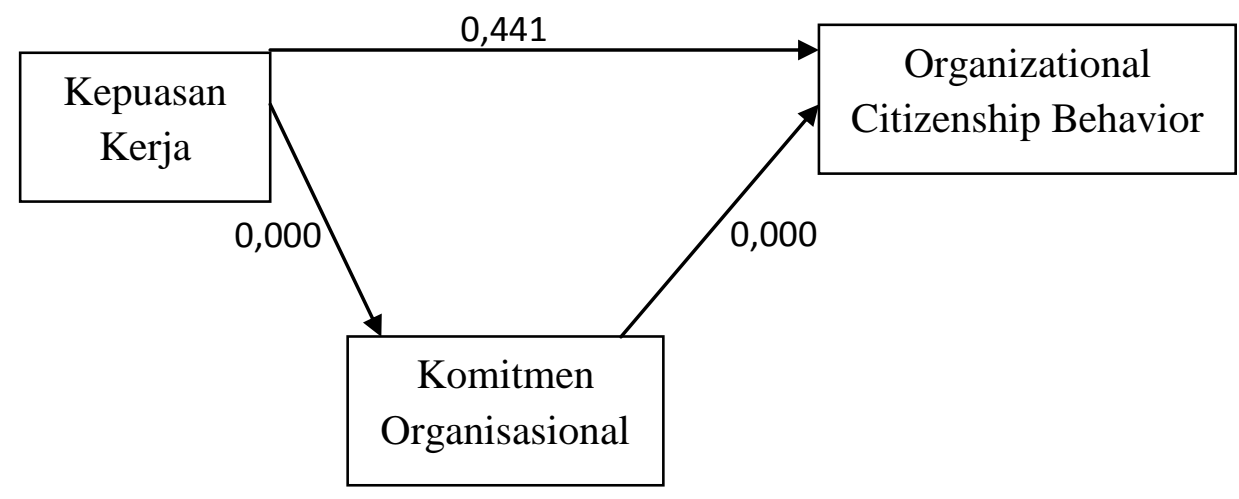

Dari gambar model penelitian di atas, dapat dilihat besarnya pengaruh antar variabel yang ditunjukkan oleh nilai-nilai yang ada pada setiap lintasan/ jalur. Untuk mengetahui validitas model penelitian di atas, dalam analisis path terdapat dua indikator, yaitu koefisien determinasi total dan theory trimming.

1. Koefisien determinasi total

Total keragaman data yang dapat dijelaskan oleh model penelitian ini diukur dengan:

$$
\begin{aligned}
\boldsymbol{R}_{m}{ }^{2} & =\mathbf{1}-\varepsilon_{1}{ }^{2} \cdot \varepsilon_{2}^{2} \\
& =1-(0,746)^{2} \cdot(0,685)^{2} \\
& =1-0,24 \\
& =0,76
\end{aligned}
$$

Dalam hal ini, interpretasi terhadap $R_{m^{2}}{ }^{2}$, sama dengan interpretasi koefisien determinasi $\left(\mathrm{R}^{2}\right)$ pada analisis regresi. Berdasarkan perhitungan di atas, diperoleh hasil koefisien determinasi total sebesar 0,76. Artinya keragaman data yang dapat dijelaskan oleh model penelitian ini adalah sebesar $76 \%$ atau dengan kata lain informasi yang terkandung dalam data $76 \%$ dapat dijelaskan oleh model penelitian ini. Sedangkan yang $24 \%$ dijelaskan oleh variabel lain (yang belum terdapat di dalam model), seperti faktor kepribadian, moral karyawan, dan motivasi kerja.

2. Theory trimming

Berdasarkan theory trimming, terdapat model jalur yang tidak sesuai dengan hipotesis dan madel jalur tersebut akan dibuang, sehingga diperoleh model sebagai berikut :.

\footnotetext{
${ }^{1}$ Mahasiswa Pasca Sarjana UNRAM Program Magister Manajemen

2 Dosen Pasca Sarjana UNRAM Program Magister Manajemen
} 
Gambar 5. Model PenelitianTheory trimming Pengaruh Kepuasan Kerja Terhadap Organization Citizenship Behavior (OCB) dengan Komitmen Organisasional Sebagai Variabel Intervening (Studi Pada Pns Rumah Sakit Umum Daerah Kabupaten Lombok Utara)

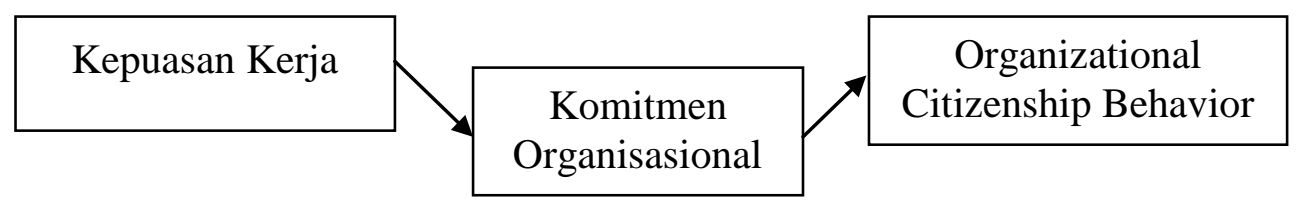

\section{PEMBAHASAN}

\subsection{Pengaruh Kepuasan Kerja terhadap OCB Pada RSUD Kabupaten Lombok Utara.}

Hasil uji hipotesis bahwa tidak terdapat pengaruh signifikan kepuasan kerja terhadap OCB PNS RSUD Kabupaten Lombok Utara, sehingga hipotesis yang diajukan ditolak atau tidak diterima. Hasil ini tidak mendukung sebagian besar hasil penelitian terdahulu yang menemukan bahwa kepuasan kerja berpengaruh secara signifikan terhadap OCB (misalnya Hastaningsih, 2007), Wijaya dan Sutanto (2014), Rusdi, Mukhlis Yunus, Syafruddin Chan, 2015). Namun hasil dari penelitian ini mendukung oleh penelitian yang dilakukan Wicaksono (2012), Rahmawati (2014), Ningsih dan Arsanti (2014), serta Mulyanti dan Rohendi (2015), yang menemukan bahwa kepuasan kerja tidak berpengaruh signifikan terhadap Organizational Citizenship Behavior OCB.

Hasil yang diperoleh dapat dipahami bahwa kepuasan kerja yang dimiliki dalam diri pegawai terhadap pekerjaannya tidak serta merta memengaruhi pegawai RSUD KLU untuk memunculkan perilaku extra/role atau OCB. Kepuasan kerja yang dibangun atas kepuasan pegawai terhadap perilaku ekstra peran atau OCB yang ditujukan puas dengan pekerjaan sekarang, antusias dengan pekerjaan, merasakan hal yang sama, kenikmatan nyata dalam pekerjaan dan pekerjaan tidak menyenangkan ternyata belum mampu untuk mendorong pegawai RSUD KLU untuk berperilaku extra/role atau OCB. Berdasarkan teori yang sudah dikembangkan masih banyak faktor lain yang dapat memengaruhi OCB karyawan.

Kepuasan kerja merupakan suatu sikap yang tentunya diharapkan oleh organisasi, namun jika kepuasan kerja karyawan tidak terpuaskan maka akan berdampak pada penurunan kinerja. Dengan kata lain, diharapkan terciptanya kepuasan kerja yang tinggi untuk menunjang kerja karyawan. Oleh karena itu karyawan mengharapkan organisasi dapat mendukung karyawan yang bekerja sehingga karyawan merasa puas dengan pekerjaan sekarang, antusias dengan pekerjaan, merasakan hal yang sama, kenikmatan nyata dalam pekerjaan dan pekerjaan menyenangkan.

Menurut Spector, (1997), menyatakan bahwa banyaknya hal yang menentukan puas atau tidak puasnya orang dalam bekerja dapat dipengaruhi oleh faktor-faktor yang menentukan kepuasan kerja yang terdiri dari dua kategori besar yaitu : pertama, lingkungan kerja itu sendiri dan faktor-faktor yang berkaitan dengan pekerjaan dan memiliki pengaruh penting pada kepuasan kerja seperti karakteristik pekerjaan, ketidakluwesan dalam organisasi, variabel peran yang merupakan pola tingkah laku yang harus dimiliki oleh individu dalam organisasi, konflik pekerjaan-keluarga, gaji,

\footnotetext{
${ }^{1}$ Mahasiswa Pasca Sarjana UNRAM Program Magister Manajemen

2 Dosen Pasca Sarjana UNRAM Program Magister Manajemen
} 
stress kerja, beban kerja, kendali, dan jadwal kerja. Kedua, faktor individu yang dibawa seseorang ke pekerjaannya seperti kepribadian, jenis kelamin, usia, perbedaan budaya dan etnis, serta pendidikan.

\subsection{Pengaruh Kepuasan Kerja terhadap Komitmen Organisasional pada RSUD Kabupaten Lombok Utara}

Hasil uji hipotesis bahwa terdapat pengaruh yang positif dan signifikan kepuasan kerja terhadap komitmen organisasional PNS RSUD Kabupaten Lombok Utara. Hal ini menunjukkan bahwa semakin baik kepuasan kerja yang dirasakan oleh pegawai maka semakin tinggi komitmen organisasional, demikian sebaliknya apabila pegawai merasa tidak puas maka akan menurunkan komitmen mereka terhadap organisasi. Kepuasan kerja yang diukur dengan item puas dengan pekerjaan sekarang, antusias dengan pekerjaan, merasakan hal yang sama, kenikmatan nyata dalam pekerjaan dan pekerjaan tidak menyenangkan, menunjukkan telah dikelola dengan baik sehingga memberikan kontribusi terhadap komitmen organisasional.

Penelitian ini mendukung penelitian yang dilakukan oleh Tania dan Sutanto (2013), Vania dan Purba (2014), Puspitawati (2014), serta Hadi (2015), dimana hasil penelitian ini membuktikan bahwa secara empiris kepuasan kerja berpengaruh positif dan signifikan terhadap komitmen organisasional.

Gregson (1992) menyatakan bahwa kepuasan kerja sebagai pertanda awal terhadap komitmen organisasi yang signifikan telah dibuktikan dalam banyak penelitian seperti Porter et al., (1974), Mottaz (1987), William dan Anderson (1991), Vanderberg dan Lance (1992), Knoop (1995), Young, Worchel dan Woehr (1998), Testa (2001) dan sebagainya. Hasil penelitian mereka menunjukkan bahwa karyawan yang merasa puas dengan pekerjaannya akan lebih memiliki komitmen yang tinggi dengan organisasinya, selanjutnya karyawan akan merasa bangga dengan keanggotaannya dalam organisasi, karyawan percaya dengan tujuan dan nilai-nilai dalam organisasi, dan pada akhirnya memberikan kinerja dan produktivitas yang tinggi (Lew Tek Yew, 2005).

Teori yang melandasi hubungan antara kepuasan kerja dengan komitmen organisasi adalah teori harapan (expectancy theory) yang dikemukakan oleh Victor $\mathrm{H}$. Vroom dalam Hasibuan (1999:116) yang menyatakan bahwa kekuatan yang memotivasi seseorang untuk bekerja giat dalam mengerjakan pekerjaannya tergantung dari hubungan timbal balik antara apa yang ia inginkan dan butuhkan dari hasil pekerjaan itu. Berapa besar ia yakin perusahaan akan memberikan pemuasan bagi keinginannya sebagai imbalan atas usaha yang dilakukannya itu. Bila keyakinan yang diharapkan cukup besar untuk memperoleh kepuasannya maka ia akan bekerja keras dan berkomitmen tinggi kepada perusahaan atau organisasinya dan sebaliknya.

Komitmen organisasional sedemikian penting untuk dipahami dan diciptakan. Terjadinya komitmen personil atau individu dalam setiap jajaran dan tingkatan organisasi berkaitan dengan sikap keberpihakan personil untuk menyatu dengan tujuan dan sasaran serta sesuai dengan nilai organisasi. Dengan demikian setiap pengelola organisasi apapun sangat berkepentingan untuk menempuh berbagai upaya strategis untuk menciptakan dan melestarikan serta meningkatkan derajat komitmen sumber daya manusia sebagai jembatan untuk mencapai efektifitas perilaku dan kinerja individu, kelompok dan organisasi.

\footnotetext{
${ }^{1}$ Mahasiswa Pasca Sarjana UNRAM Program Magister Manajemen

2 Dosen Pasca Sarjana UNRAM Program Magister Manajemen
} 
Sebagai salah satu sumber daya yang penting bagi perusahaan karyawan dituntut untuk memberikan kontribusi dan bekerja bagi tercapainya tujuan-tujuan organisasi.Tujuan-tujuan organisasi dapat tercapai melalui tingginya komitmen organisasional karyawan yang dipengaruhi oleh kepuasan kerja. Kepuasan kerja memiliki hubungan yang positif terhadap komitmen organisasional (Johntson, et al., 1990). Pendapat ini diperkuat dengan hasil kajian yang dilakukan (Podsakoff et al., 2003) yang memperlihatkan hubungan signifikan dan positif kepuasan kerja karyawan terhadap komitmen organisasional. Penelitian ini memperlihatkan bahwa komitmen organisasional merupakan konsekuensi dari kepuasan kerja karyawan (Brown dan Peterson, 1993).

\subsection{Pengaruh Komitmen Organisasional terhadap OCB pada RSUD Kabupaten Lombok Utara}

Hasil uji hipotesis membuktikan terdapat pengaruh yang positif dan signifikan komitmen organisasional terhadap OCB.

Hasil penelitian mendukung penelitian yang dilakukan oleh Hastaningsih (2007), Rini (2013), Vania dan Purba (2014), dimana hasil penelitian ini membuktikan bahwa komitmen organisasional berpengaruh signifikan terhadap Organizational Citizenship Behavior (OCB). Selain itu, penelitian yang dilakukan oleh Setiawan, (2009) membuktikan bahwa komitmen organisasional berpengaruh positif terhadap OCB. Semakin tinggi tingkat komitmen organisasional maka semakin tinggi kerelaan pegawai dalam melakukan pekerjaan-pekerjaan diluar deskripsi pekerjaan.

Komitmen organisasional merupakan identifikasi rasa, keterlibatan loyalitas yang ditampakkan oleh pekerja terhadap organisasinya atau unit organisasi (Gibson et al., 1982 dalam Supriyanto, 2000,59). Selanjutnya Meyer et al.,1993, Mendefinisikan komitmen organisasional sebagai sikap positif seseorang terhadap organisasi.sikap ini akan mendorong orang untuk berprilaku positif, disiplin dalam bekerja, mentaati kebijakan dan peraturan organisasi, menjalin hubungan baik dengan rekan kerja, serta meningkatkan prestasi kerja.

Mowday, Steers dan Porter (1979) berpendapat komitmen organisasional menjadi kekuatan relatif dari identifikasi individu dengan keterlibatan didalam organisasi. Scholl (1981) dan Weiner (1982) memberikan dukungan teoritis untuk hubungan komitmen-OCB. Model Scholl ini mengidentifikasi komitmen sebagai kekuatan bertindak untuk menjaga arah perilaku ketika kondisi harapan atau hak keadilan karyawan pada organisasi tidak terpenuhi dan tidak berfungsi. OCB mewakili perilaku yang terjadi ketika karyawan sedikit mengharapkan imbalan organisasi formal untuk kinerja mereka, komitmen merupakan penentu kemungkinan karyawan melakukan OCB. Dalam model Weiner komitmen dipandang sebagai totalitas keyakinan dan bertanggungjawab atas perilaku yang (a) mencerminkan pengorbanan pribadi yang dilakukan untuk kepentingan organisasi; (b) tidak tergantung terutama pada penguatan atau hukuman, dan (c) menunjukkan kesenangan pribadi terhadap organisasi. karena karakteristik ini maka dapat dijelaskan komitmen organisasional sebagai sesuatu yang mendahului OCB.

\footnotetext{
${ }^{1}$ Mahasiswa Pasca Sarjana UNRAM Program Magister Manajemen

2 Dosen Pasca Sarjana UNRAM Program Magister Manajemen
} 


\subsection{Pengaruh Kepuasan Kerja terhadap OCB melalui Komitmen Organisasional PNS Pada RSUD Kabupaten Lombok Utara.}

Hasi uji hipotesis membuktikan terdapat pengaruh yang positif dan signifikan Kepuasan Kerja terhadap OCB melalui Komitmen Organisasional. Hasil penelitian ini mendukung penelitian yang di lakukan oleh Hastaningsih (2007), Hardianti (2013), Wijaya dan Sutanto (2014), membuktikan bahwa Kepuasan Kerja berpengaruh signifikan terhadap OCB melalui Komitmen Organisasional. Dalam penelitian yang dilakukan oleh Vania dan Purba (2014), menjelaskan literatur teoritis mendukung beberapa konsep, baik ditingkat individu dan organisasi untuk membantu menjelaskan OCB.

Menurut Robbins dan Timoty (2008:99), keberhasilan dan kinerja seorang karyawan dalam bidang pekerjaannya ditentukan oleh beberapa faktor diantaranya adalah kepuasan kerja, keterlibatan kerja serta komitmennya pada organisasi. Kepuasan kerja (job satisfaction) merujuk pada sikap umum seorang individu terhadap pekerjaannya. Seseorang dengan tingkat kepuasan kerja tinggi menunjukkan sikap yang positif terhadap kerja itu, seseorang yang tidak puas dengan pekerjaannya menunjukkan sikap yang negatif terhadap pekerjaan itu yang mencerminkan kurangnya komitmen terhadap perusahaan seperti tingginya turnover karyawan, tingginya absensi, meningkatnya kelambanan kerja dan kurangnya intensitas untuk bertahan sebagai karyawan di organisasi, rendahnya kualitas kerja, kurangnya loyalitas, dan tingginya kemangkiran dari tugas dan tanggung jawab. Keterlibatan kerja (job involvement) mengukur derajat sejauh mana seseorang memihak secara psikologis pada pekerjaannya dan menganggap tingkat kinerjanya yang dipersepsikan sebagai penting untuk harga diri (Purwati, dan Anjanarko, 2015: 19-20).

Menurut Schnake (1991; Organ \& Ryan, 1995), sikap individu dari (1) kepuasan kerja telah secara teoritis dikaitkan dengan OCB (Bateman \& Organ, 1983), (2) komitmen organisasi juga telah terhubung ke OCB (Bolon, et.al, 1991). Menurut Robbins dan Timothy (2008:100) menyatakan bahwa komitmen organisasi adalah sebagai suatu keadaan di mana seorang karyawan memihak pada suatu organisasi tertentu serta tujuan-tujuan dan keinginan untuk mempertahankan keanggotaan dalam organisasi tersebut. Jadi keterlibatan kerja yang tinggi berarti pemihakan seseorang pada pekerjaan tertentu seseorang, sedangkan komitmen pada organisasi yang tinggi berarti pemihakan pada organisasi tempat bekerja". Oleh karena itu setiap perusahaan selayaknya mampu mengelola karyawan yang merupakan aset dengan baik karena dengan pengelolaan yang baik akan diperoleh kepuasan karyawan dalam bekerja, melalui kepuasan kerja ini diharapkan akan diperoleh karyawan yang mempunyai komitmen kuat pada perusahaan maupun karyawan itu sendiri.

Berdasarkan penjelasan banyak ahli bahwa kepuasan kerja dan komitmen organisasional dapat memengaruhi $\mathrm{OCB}$, maka disimpulkan bahwa kepuasan kerja berhubungan positif dengan OCB melalui komitmen organisasional sebagai variabel intervening.

\footnotetext{
${ }^{1}$ Mahasiswa Pasca Sarjana UNRAM Program Magister Manajemen

2 Dosen Pasca Sarjana UNRAM Program Magister Manajemen
} 


\section{KESIMPULAN}

Berdasarkan hasil penelitian dan pembahasan tentang Pengaruh Kepuasan

Kerja Terhadap Organizational Citizenship Behavior (OCB) dengan Komitmen Organisasional Sebagai Variabel Intervening, dapat disimpulkan:

a. Kepuasan Kerja berpengaruh positif, relatif sangat kecil dan tidak signifikan terhadap Organizational Citizenship Behavior.

b. Kepuasan Kerja berpengaruh positif dan signifikan terhadap Komitmen Organisasional.

c. Komitmen Organisasional berpengaruh positif dan signifikan terhadap Organizational Citizenship Behavior.

d. Kepuasan Kerja berpengaruh positif dan signifikan terhadap Organizational Citizenship Behavior melalui Komitmen Organisasional.

\section{REKOMENDASI}

Berdasarkan hasil penelitian dan pembahasan, serta kesimpulan maka ada beberapa saran yang dapat dikemukakan dalam rangka meningkatkan Kepuasan Kerja, Komitmen Organisasional dan OCB PNS RSUD KLU sebagai berikut:

a. Hasil penelitian membuktikan bahwa komitmen organisasional berpengaruh terhadap OCB pegawai. Dari hasil penelitian ini komitmen organisasional merupakan variabel yang dapat memediasi kepuasan kerja terhadap OCB PNS RSUD KLU. Oleh karena itu pihak RSUD Kabupaten Lombok Utara tidak perlu mengkhawatirkan terjadinya turnover karyawan atau pegawainya bila dilihat dari variabel kepuasan kerja, komitmen organisasional dan OCB yang cukup baik.

Bagi RSUD Kabupaten Lombok Utara untuk terus mempertahankan dan meningkaatkan kebijakan yang dapat mendorong karyawan untuk maju dan melakukan evaluasi serta pendekatan pada pegawai untuk memahami kondisi pegawainya. Serta ditingkatkan lagi komitmen PNS dalam hal kesetiaan terhadap organisasi. Sedangkan untuk organisasi dapat meningkatkan lagi hal yang memberikan manfaat terhadap pekerjaan setiap PNS yang ada di RS. Dari beberapa hal ini dinilai oleh responden terbukti pada penilaian kategori rendah.

b. Mengacu pada kesimpulan yang menyatakan bahwa kepuasan kerja tidak berpengaruh signifikan terhadap OCB PNS RSUD KLU. Dilihat dari beberapa tugas dan tanggungjawab pegawai RSUD KLU sangat kompleks, namun tugas dan tanggungjawab tersebut dapat di jalankan dengan baik dan efektif terhadap pekerjaannya. Hal ini terlihat adanya komitmen yang dibentuk dalam diri individu sehingga mereka mau bekerja melebihi perannya. Dimana OCB pegawai RSUD KLU sangat tinggi yang ditunjukan dengan adanya respon bersedia untuk berperilaku ekstra peran melebihi tugas dan tanggungjawabnya sebagai pegawai pada RSUD KLU.

Dari hasil penelitian, diketahui bahwa kepuasan kerja PNS masih ada beberapa hal yang perlu ditingkatkan sehingga secara keseluruhan PNS RSUD KLU merasa puas. Beberapa hal yang perlu ditingkatkan yaitu dalam hal "memberikan pekerjaan sesuai dengan tupoksi pada bidang pekerjaan masing-masing yaitu pimpinan RSUD KLU harus menempatkan karyawan sesuai dengan bidang pendidikan dan keahliannya sehingga para karyawan tidak merasa pekerjaan yang

\footnotetext{
${ }^{1}$ Mahasiswa Pasca Sarjana UNRAM Program Magister Manajemen

2 Dosen Pasca Sarjana UNRAM Program Magister Manajemen
} 
dilakukan terbebani disetiap kerja". Ini terbukti bahwa masih ada beberapa karyawan yang menganggap pekerjaannya belum menyenangkan dengan kategori tidak puas.

\section{DAFTAR PUSTAKA}

Bateman and Organ, D.W, T.S., 1983. Job Satisfaction and The Good Soldier: The Relationship Between Effect and Employee "Citizenship", Academy of Management Journal, 26 : pp-258-595.

Birnbaum, D., and Somers, M.J., 1998. Work-Related Commitment and Job Performance: It's Also The Nature of The Performance That Counts. Journal of Organizational Behavior, (19) : 621-634

Brown, S.P. dan Peterson, R.A. 1993. Antecedents and consequences of salesperson job satisfaction: meta-analysis and assessment of clausal effects. Journal of Marketing Research, Vol. 58, No. 2, pp. 70-80.

Chen, Z.X., Francesco, A.M. (2000). Employee Demography, Organizational Commitment, and Turnover Intentions in China: Do Cultural Differences Matter? Human Relations, 53, 869-887.

Ensher, Ellen A, Grant-Vallone, Elisa J, Donaldsom Steward I. 2001. Effect of Perceived Discrimination on Job Satisfaction, Organizational Commitment, Organizational Citizenship Behavior, and Grievances, Human Resources Development Quarterly, 12 (1) :pp53-72.

Fitrijayanti, Diana, 2014, “Pengaruh Quality Of Work Life (QWL) dan Kepercayaan Kepada Pimpinan Terhadap Organizational Citizenship Behavior (OCB) melalui Komitmen Organisasi (studi pada Balai Latihan Kerja Pemerintah Sepulau Lombok). Tesis Program Pascasarjana Magister Manajemen Universitas Mataram.

Gregson.T. 1992. An Investigation of the causal orderimg of job satisfaction and organizational commitment in turnover models in accounting. Behavior Research In Accounting. $4: 80$ - 95

Hadi, A., (2015), "Pengaruh Kepuasan Kerja dan Keterlibatan Kerja terhadap Komitmen Organisasional dan Kinerja. Tesis Program Magister Manajemen Ekonomi dan Bisnis.

Hastaningsih, D., (2007), "Pengaruh Kepuasan Kerja dan Komitmen Organisasional terhadap Organizational Citizenship Behavior (OCB) (Studi Kasus pada PT. Sinar Surya Indah Sukoharjo). Jurnal Manajemen.

Hasibuan, M.S.P., 1999, “ Manajemen Dasar, Pengertian dan Masalah ”, Buku I ,Jakarta : CV. Haji Masagung.

Hardianti, C.A., (2013), “Pengaruh Kepuasan Kerja dan Komitmen Organisasional terhadap Organizational Citizenship Behavior (OCB) pada Karyawan Koperasi Pamardi Utomo Semarang. Jurnal Manajemen Ekonomi dan Bisnis.

Johnston, M. W., Parasuraman, Charles M. F. \& William C. B. 1990. A Longitudinal Assesmeny of The Impact of Selected Organizational Influence on Salespeople's Organizational Commitment During Early Employment. Journal of Marketing Research, 27 (3): pp333-344.

\footnotetext{
${ }^{1}$ Mahasiswa Pasca Sarjana UNRAM Program Magister Manajemen

2 Dosen Pasca Sarjana UNRAM Program Magister Manajemen
} 
Luthans, F., 2001. Organizational Behavior, Ninth Edition, McGraw Hill, Boston.

McClelland.1987. The Achieving Society, Litton Educational Publishing Inc, USA.

Mulyanti, D., dan Rohendi, A., (2015), "Pengaruh Kepuasan Kerja Dan Komitmen Organisasi Terhadap Perilaku Pegawai (Organizational Citizenship Behavior) Pada Karyawan Rumah Sakit Dustira Cimahi", Jurnal Manajemen.

Meyer, J.P., Allen, N.J. and Smith, C.A., 1993, "Commitment to Organisations and Occupations: Extension and test of a Three- Component Conceptualisation", Journal of Applied Psychology, 78, 4, pp.538-551

Mowday, R.T., Porter LW., dan Steers, R.M., 1979, Employee-Organizational Linkages : The Psychology Of Commitment, Absenteeism And Turnover: Academic Press, New York.

Ningsih, F.R., dan Arsanti, T.A., (2014), "Pengaruh Job Satisfaction Terhadap OCB dan Turnover Intention", Jurnal Manajemen dan Bisnis, 18 (1) : pp41-48

Ngadiman et al., 2013," Influence of Transformational Leadership and Organizational Climate to The Work Satisfaction, Organizational Commitment and Organizational Citizenship Behavior on The Educational Personnel of Sebelas Maret University, Surakarta", Education Research International, 1 (1) : pp 41-66.

Nurmayanti, S., 2014, Konflik Pekerjaan Keluarga Pengaruhnya Terhadap Kepuasan Kerja Dan Komitmen Guru (studi pada Guru Wanita Sekolah Menengah di Kota Mataram). Disertasi Pascasarjana Fakultas Ekonomi dan Bisnis Universitas Brawijaya Malang.

Organ, Dennis W., et al. 2006. Organizational Citizenship Behavior. It's Nature, Antecendences, And Consequences.California:Sage Publications, Inc.

Organ, D.W., and Ryan, K., 1995. A Meta-Analytic Review of Attitudinal and Dispositional Predictor of Organizational Citizenship Behavior. Personnel Psych. 48:775-802.

Paramita, Arina dan Ratna, 2008, Analisis Faktor-faktor yang Mempengaruhi OCB Pegawai Kontrak (Studi Pegawai Kontrak di Universitas di Ponegoro Semarang). Tesis Program Magister Manajemen Universitas Diponegoro Semarang.

Podsakoff, P. M., MacKenzie, S. B., Lee, J-Y., dan Podsakoff, N. P. 2003. Common Method Biases in Behavioral Research: A Critical Review of The Literature and Recommended Remedies. Journal of Applied Psychology, 88 : pp79-903.

Podsakoff, P. M., Mackenzie, S. B., Paine J. B., dan Bancrach, D. G. 2000. Organizational Citizenship Behaviors : A Critical Review of The Theoritical And Empirical Literature and Suggestions for Fiture Research. Journal org Management, 26 : pp513563.

Pradhiptya, A.R., (2013), “Pengaruh Kepuasan Kerja terhadap Organizational Citizenship Behavior (OCB) dengan Mediasi Komitmen Organisasional", Jurnal Ilmu Manajemen, 1 (1) : pp342-352.

Puspitawati, N.M.D., (2014), “Pengaruh Kepuasan Kerja Terhadap Komitmen Organisasional dan Kualitas Layanan", Jurnal Manajemen Strategi Bisnis Dan Kewirausahaan, 8 (1) : pp68-80.

Purwanti, E., dan Anjanarko, T.S., 2015, “Pengaruh Faktor-Faktor Kepuasan Kerja Terhadap Komitmen Organisasi Karyawan Bagian Administrasi Pada PT. Perkebunan Nusantara X ( PERSERO ) unit usaha PG. Toelangan - sidoarjo. Jurnal Ebis, 7 (1) :pp19-38.

\footnotetext{
${ }^{1}$ Mahasiswa Pasca Sarjana UNRAM Program Magister Manajemen

2 Dosen Pasca Sarjana UNRAM Program Magister Manajemen
} 
Profil Rumah Sakit Umum Daerah Kabupaten Lombok Utara Tahun 2014.

Rahmawati, 2014, Pengaruh Iklim Organisasi Dan Kepuasan Kerja Terhadap Organizational Citizenship Behavior (OCB) (Studi Pada Guru Non PNS SMKN se Kabupaten Lombok Barat). Tesis Program Pascasarjana Magister Manajemen Universitas Mataram.

Rini, D. P., Rusdiardi, Suparjo, 2013, 'Pengaruh Komitmen Organisasi, Kepuasan Kerja Dan Budaya Organisasi Terhadap Organizational Citizenship Behavior (OCB) Sudi Pada PT. Plasa Simpanglima Semarang', Jurnal Ilmiah Dinamika Ekonomi dan Bisnis Fakultas Ekonomi Untag Semarang, 1 (1) :pp 69-88.

Rohayati, A, 2015,'Pengaruh Kepuasan Kerja terhadap Organizational Citizenship Behavior (OCB) :studi pada masyarakat madani Indonesia" Jurnal smart study \& Management research, 11 (1) : pp 20-38.

Robbins, S.P., 2001. Perilaku Organisasi Konsep Kontroversi Aplikasi, Edisi 8, Jilid 1, Terjemahan, Jakarta: Prehalindo. 2006. Perilaku Organisasi. Jakarta :Indeks.

Robbins, S.P., dan Judge, T.A.,. 2008. Perilaku Organisasi. Buku 1.Cet. 12.Jakarta :Salemba Empat.

England : Pearson Education.

(2013). Organizational Behavior (15 th ed.) Global Edition.

Rusdi, Yunus, M. Chan, S., 2015, ‘Pengaruh Kepuasan Kerja dan Loyalitas Karyawan Terhadap Organizational Citizenship Behavior (OCB) Serta Dampaknya Pada Efektivitas Perusahaan PT. MARKPLUS. INC.', Jurnal Manajemen Universitas Syiah Kuala, 4 (2) :pp 149-159.

Setiawan, H., 2009. Pengaruh Komitmen Organisasional Terhadap Kepuasan Kerja Dengan Organizational Citizenship Behavior (OCB) Sebagai Variabel Intervening (Studi Pada Inspektorat Kabupaten Temanngung. Tesis Program Magister Akuntansi Universitas Diponegoro, Semarang.

Spector, P. E., 1997. Job Satisfaction. USA : SAGE Publications, Inc.

Sopiah. 2008. Perilaku Organiasi, Yogyakarta :Andi.

Supriyanto, Ahmad. 2000. Pengaruh Perilaku Pimpinan Dalam Pengambilan Jeputusan Terhadap Komitmen Karyawan Pada Program Implementasi SJM ISO-9001, Thesis, Program Pascasarjana Universitas Brawijaya, Malang.

Sugiyono. 2011. Metode Penelitian Pendidikan. Bandung :Alfabeta.

Titisari, P., (2014), Peranan Organizational Citizenship behavior (OCB) Dalam Meningkatkan Kinerja Karyawan. Jakarta :MitraWacana Media.

Tania, A., dan Sutatnto, E.M., (2013), "Pengaruh Motivasi Kerja dan Kepuasan Kerja terhadap Komitmen Organisasional Karyawan PT. Dai Knife Di Surabaya", Jurnal AGORA, 1 (3) : pp1-7.

Vania, L., dan Purba, S., D., 2014, 'Pengaruh Job Satisfaction Terhadap Organizational Citizenship Behavior (OCB) Dengan Organizational Commitment SebagaiVariabel Intervening Pada Rumah Sakit Pantai Indah Kapuk Di Jakarta', JurnalManajemen, 11 (2) : pp 1-22.

Wijaya, F.J., dan Sutanto, E.M., (2014),"Pengaruh Komitmen rganisasional dan Kepuasan Kerja Karyawan terhadap Organizational Citizenship Behavior (OCB) di PT. XYZ Surabaya. Jurnal AGORA, 2 (2) :pp1-6

\footnotetext{
1 Mahasiswa Pasca Sarjana UNRAM Program Magister Manajemen

2 Dosen Pasca Sarjana UNRAM Program Magister Manajemen
} 
$J M M$

UNRAM
JURNAL MAGISTER MANAJEMEN

UNIVERSITAS MATARAM

September 2016

Wexley, K.N. \&, Yukl, L.A. (1998). Organizational Behavior and Personnel Pshcology.Bostonn: Richard D Irwin, Inc.

Wiener, Y., 1982, Commitment in Organizations: A normative view. Academy of Management Review, 7, 418-428.

Wicaksono, D.S., (2012), “Analisis Pengaruh Organizational Citizenship Behavior (OCB) dan Komitmen Organisasional Terhadap Kinerja Dengan Mediasi Kepuasan Kerja (studi pada PT. BPR Nusamba Cepiring)", Journal of Accounting and Banking, 1 (1). 